\title{
Dynamics of Blue Grama within a
}

\section{Shortgrass Ecosystem}

\author{
D. W. URESK, P. L. SIMS, AND D. A. JAMESON
}

Highlight: The dynamics of standing crop for live, dead, and litter compartments of blue grama were studied for 2 years to formulate equations useful for predicting growth rates over 2-week intervals. During the period of rapid vegetative growth, $54 \%$ of the variation in rates of changes for live herbage was accounted for by the amount of live herbage present at a given time. During the declining period, the amount of live herbage, leaf moisture, and air temperature accounted for $58 \%$ of the variation in net changes. The transfer rate from live to dead herbage was $0.22 \%$ of the live herbage per day during the growing season, while litter accumulated from the dead herbage at a rate of $0.31 \%$ per day. This transfer rate became $0.086 \%$ per day during the non-growing season. Litter decomposed during the growing season at a rate of $0.35 \%$ per day.

Blue grama (Bouteloua gracilis (H.B.K.) Lag. ex. Steud.) is the major forage species in the shortgrass ecosystem and is important on well over 200 million acres in the Great Plains in the United States (Stoddart and Smith, 1955). Understanding the dynamics of blue grama herbage is basic to understanding nutrient cycling and energy flow through this important species. Furthermore, this is one of the first steps in developing a greater understanding of the structure and function of such ecosystems.

\section{Description of Study Area}

The study area is located within a shortgrass ecosystem on the Pawnee National Grassland and the Central Plains Experimental Range about $13 \mathrm{~km} \mathrm{N.E.} \mathrm{of} \mathrm{Nunn,} \mathrm{Sections} 15$ and 23, Township $10 \mathrm{~N}$, Range $66 \mathrm{~W}$ in Weld County, Colorado. The climate of the area is semiarid with a 29 year (1939-1967) average annual precipitation of about 31 $\mathrm{cm} /$ year, varying from a maximum of $58 \mathrm{~cm}$ to a minimum of $11 \mathrm{~cm}$ (Bement, 1968). Most precipitation falls as rain, with an average of $23 \mathrm{~cm}$ during the growing season. Wind velocity averages $11 \mathrm{~km} /$ hour and the mean high and low temperatures are $26^{\circ}$ and $8^{\circ} \mathrm{C}$, respectively. The frost-free season averages 135 days.

The climatic conditions for the Pawnee Site were tabulated for the sampling period of 1969 and 1970 (Table 1). Temperatures ranged from about $9^{\circ} \mathrm{C}$ in early spring 1969 to more than $21^{\circ} \mathrm{C}$ during mid-summer. Winter temperatures of $1969-1970$ averaged between $1^{\circ}$ and $4^{\circ} \mathrm{C}$. Summer temperatures were similar for both years averaging between

At the time of the study, authors were graduate research assistant, associate professor, and professor, Department of Range Science, Colorado State University, Fort Collins. At present the senior author is research scientist, Terrestrial Ecology Section, Ecosystems Department, Battelle Northwest, Richland, Washington.

This paper reports on work supported in part by National Science Foundation Grant GB-7824, GB-13096, and GB-41233X to the Grassland Biome, U. S. Int ernational Biological Program, for "Analysis of Structure, Function, and Utilization of Grassland Ecosystems."

Manuscript received June 21, 1974.

$15^{\circ}$ and $21^{\circ} \mathrm{C}$. Soil moisture data for the sampling site wi not available for 1969. In 1970 the average soil moistı measured with a neutron probe placed at a $15 \mathrm{~cm}$ der decreased from a high of $3.2 \mathrm{~cm}$ of water in early spring about $1.5 \mathrm{~cm}$ in early September. Precipitation during $t$ growing season of 1969 was considerably higher than tl occurring in 1970. This was due primarily to heavy ra during the early spring between May 19 and June 21 . F precipitation was also greater in 1969 than in 1970 by abou $\mathrm{cm}$, which fell between September 9 and October 25 . T precipitation occurred in the form of snow and accounts 1 the high soil moisture conditions at the beginning of the 19 growing season. Thus, the conditions during the growi season appear to be more favorable in 1969 than in 1970 .

Since 1939 three pastures have been subjected to lig moderate, and heavy summer grazing by cattle (Klipple a Costello, 1960). These treatments were regulated so that 6( of the current herbage growth of dominant forage grasses $\mathrm{k}$ grazed by the end of the season on heavy use pastures, $40 \%$. moderate use pastures, and $20 \%$ on the light use pastur Cattle grazed these study areas from May 1 to September ? Enclosures fenced since 1939 to prevent grazing by cat

Table 1. Average air temperature $\left({ }^{\circ} \mathrm{C}\right)$, precipitation $(\mathrm{cm})$, and : water $(\mathrm{cm})$ between sampling dates in 1969 and 1970.

\begin{tabular}{cccr}
\hline Year and dates & Air temp. & Soil water ${ }^{2}$ & Precipitati \\
\hline 1969 & & & \\
Mar. 27 & 0.2 & $-{ }^{4}$ & \\
May 18 & 9.2 & - & 9.73 \\
June 21 & 12.9 & - & 10.85 \\
June 30 & 14.7 & - & 1.27 \\
July 14 & 18.9 & - & 1.27 \\
July 29 & 21.5 & - & 3.05 \\
Aug. 11 & 21.8 & - & 1.88 \\
Aug. 24 & 20.7 & - & 0.18 \\
Sept. 8 & 19.3 & - & 1.98 \\
Oct. 25 & 10.1 & & 9.02 \\
Dec. 16 & 1.2 & 2.7 & 1.12 \\
1970 & & 3.2 & \\
Apr. 9 & 1.6 & 2.1 & 3.63 \\
May 5 & 4.0 & 2.0 & 3.35 \\
May 19 & 11.4 & 2.2 & 0.05 \\
June 1 & 13.6 & 1.6 & 2.08 \\
June 16 & 12.7 & 1.9 & 2.90 \\
June 29 & 19.8 & 1.8 & 0.00 \\
July 15 & 20.4 & 1.7 & 1.14 \\
July 29 & 20.8 & 1.6 & 2.69 \\
Aug. 11 & 22.1 & 1.5 & 0.74 \\
Aug. 24 & 20.6 & 0.00 \\
Sept. 8 & 18.4 & 0.46 \\
\hline
\end{tabular}

${ }^{1}$ Mean air temperature derived from daily maximum and minimı readings from Central Plains Experimental Range.

${ }^{2}$ Total soil water measured with a neutron probe at a $15 \mathrm{~cm} \mathrm{de}$ (mean of eight replicates) obtained from A. F. Galbraith, $1971 \mathrm{P}$ ? Thesis, Colorado State University.

${ }^{3}$ Precipitation obtained from Central Plains Experimental Range.

${ }^{4}$ Data not available. 
comprised the fourth treatment.

Blue grama, the dominant species of plant, makes up about $43 \%$ of the total dry weight of herbage. Other grass species and their percentage composition by weight are red threeawn (Aristida longiseta Steud.), 8\%; buffalograss (Buchloe dactyloides (Nutt.) Engelm.), 2\%; sand dropseed (Sporobolus cryptandrus (Torr.) A. Gray), 1\%; and sunsedge (Carex heliophila Mack.), 3\%. Shrubs comprise about $7 \%$ of the total dry weight of the standing vegetation and common shrubs include fringed sagewort (Artemisia frigida Willd.), rubber rabbitbrush (Chrysothamnus nauseosus (Pall.) Britt.) and broom snakeweed (Gutierrezia sarothrae (Pursh) Britt. and Rusby). Forbs make up about $6 \%$ of the total dry weight of standing vegetation. Common forbs include scarlet globemallow (Sphaeralcea coccinea (Pursh) Rybd.), evening primrose (Oenothera spp. L.), and plains bahia (Bahia oppositifolia (Nutt.) D.C.). Plains pricklypear (Opuntia polyacantha Haw.) makes up ahout $26 \%$ of the total dry weight of the standing vegetation and is widespread throughout the study area. Litter comprises about $50 \%$ of the aboveground biomass, which includes all species of plants.

\section{Methods}

The three study areas were sampled while being grazed by cattle during 1969 and 1970. A fourth study area used as a control had not been grazed by cattle since 1939. Within each of the four study areas there were two replicates located adjacent to micro-watersheds (Smith and Striffler, 1969). All replicates were located on Ascalon sandy loam soil on uniform slopes, varying in size from 0.25 to 0.50 ha. The eight replicates were sampled with clipped plots once in the pre-growing season and biweekly during the season of rapid vegetative growth and flowering for 1969 and 1970. In 1969, one sampling period was during the post-growing season.

During 1969, standing vegetation on each of the eight replicates for the pre-growing and biweekly sampling periods was sampled within four $50-\mathrm{cm} \times 50-\mathrm{cm}\left(0.25 \mathrm{~m}^{2}\right)$ plots. Four plots were located randomly on each replicate. A minimum of 12 circular $1-\mathrm{m}^{2}$ plots were located randomly within each replicate during the post-growing season of sampling in 1969. In 1970 , the vegetation was sampled with eight $0.25 \mathrm{~m}^{2}$ plots located randomly within each replicate.

Permanent reference points were located in the field and numbered within each replicate for the last sampling period of 1969. Each reference point was located about 6 meters apart in a grid design. All of these reference points were used for selecting random plots throughout the 1970 sampling season.

All plots were clipped near ground level and the clippings sorted and sacked by species. Litter remaining on the plots after clipping was raked by hand and sacked. Net weights were obtained to the nearest $0.5 \mathrm{~g}$ for each species of plant and litter, in the field.

Two $25-\mathrm{cm}$ by $25-\mathrm{cm}$ plots were selected at random on each replicate in 1969 to determine the amount of standing live (green portion) and dead (tan portion) of blue grama by dates. During 1970, on each clipping date, two of the $0.25 \mathrm{~m}^{2}$ plots were selected at random from the eight clipped plots on each replicate. Blue grama herbage from these plots was hand separated into live and dead categories and weighed. Weights of vegetation from each plot separated as to live or dead were converted to percentages. These values were then converted to $\mathrm{g} / \mathrm{m}^{2}$ from the total standing crop of live and dead for each replicate.

The samples of standing vegetation and litter were dried in a forced air oven for 48 hours at $60^{\circ} \mathrm{C}$. Oven-dry weights were obtained to the nearest 0.1 gram. Blue grama was combined by replicates for each date after oven-dry weights were obtained. A subsample from each replicate by dates was ashed in a muffle furnace for four hours at $650^{\circ} \mathrm{C}$ and all values were orrected to an ash-free basis.

One litter subsample from each replicate on each sampling date was ashed and all litter values were corrected to an ash-free basis. Five microscope slides were made of the ground litter by replicates and dates (Cavender and Hansen, 1970). Twenty microscopic fields were read per slide to determine percentage composition of each species and converted to grams per square meter (Fracker and Brischle, 1944; Sparks and Malechek, 1968; Hansen and Flinders, 1969).

Precipitation and temperature data were obtained from the Central Plains Experimental Range for 1969 and 1970. Soil moisture data (total water at a $15 \mathrm{~cm}$ depth) for 1970 were obtained from Galbraith (1971).

\section{Results and Discussion}

When the impact of cattle grazing in the shortgrass ecosystem is studied, other animals must also be considered. Amounts of forage grazed by animals and their impact on herbage yield are difficult to measure (Howard, 1962). Small mammals showed much seasonal variation in the types and amounts of different species of plant eaten (Flake, 1973; Flinders and Hansen, 1972), as did insects (Yount, 1971). Some mammals were found to congregate in areas ungrazed by cattle (Costello and Turner, 1941). Since information on herbage losses caused by animals and weathering is not available, no attempt was made to determine their impact upon the different grazing treatments.

\section{Predicting Net Rates of Changes for Live Herbage}

Frequently, one or two specific factors may influence or show a relationship with rates of changes in herbage. If these factors can be isolated and reliably measured and related to these changes, then changes in herbage may be predicted. A close relationship between precipitation and peak standing crop was found by Smoliak (1956) on ranges in Alberta, by Currie and Peterson (1966) in Colorado, Rauzi (1964) in Wyoming, Albertson (1966), Hulett and Tomanek (1969), and Shiflet and Dietz (1974) working on ranges in Kansas. Dahl (1963) related total yields of herbage with precipitation of the previous 2 years and predicted yields from soil moisture.

To predict changes in live blue grama herbage, abiotic factors, plant status, and the-amount of herbage at a given

Table 2. Regression analyses showing the influence of the amount of live blue grama herbage and leaf moisture on change in herbage weight (Y) at different periods of the season.

\begin{tabular}{|c|c|c|}
\hline Equation $^{2}$ & $\mathbf{R}^{2}$ & $\sigma^{2}$ \\
\hline \multicolumn{3}{|l|}{ Rising period } \\
\hline 1. $\mathrm{Y}=0.476$ & & 0.25 \\
\hline 2. $\mathrm{Y}=1.021-0.031 \mathrm{WT}$ & $0.40 * * 2$ & 0.15 \\
\hline 3. $\mathrm{Y}=0.628+0.041 \mathrm{WT}-0.0021 \mathrm{WT}^{2}$ & $0.47 * *$ & 0.12 \\
\hline \multicolumn{3}{|l|}{ Declining period } \\
\hline 4. $Y=0.263$ & & 0.35 \\
\hline 5. $\mathrm{Y}=0.761-0.041 \mathrm{WT}$ & $0.42 * *$ & 0.20 \\
\hline 6. $\mathrm{Y}=0.419-0.048 \mathrm{WT}+0.900 \mathrm{LM}$ & $0.47 * *$ & 0.19 \\
\hline \multicolumn{3}{|l|}{$\begin{array}{l}\text { Declining period after maximum rates } \\
\text { of change (Y) occur in Equation } 3 \text {. }\end{array}$} \\
\hline 7. $\mathrm{Y}=-0.091$ & & 0.42 \\
\hline 8. $\mathrm{Y}=1.050-0.047 \mathrm{WT}$ & $0.42 * *$ & 0.24 \\
\hline 9. $\mathrm{Y}=0.367-0.562 \mathrm{WT}+1.431 \mathrm{LM}$ & $0.55 * *$ & 0.19 \\
\hline 10. $\mathrm{Y}=1.281-0.050 \mathrm{WT}+1.122 \mathrm{LM}-0.046 \mathrm{~T}$ & $0.58 * *$ & 0.18 \\
\hline
\end{tabular}


time were analyzed by stepwise regression according to Draper and Smith (1968). Since no significant differences were found between years, data for the 2 years were combined (Uresk, 1971). Analyses were separated into two periods. First, regression equations were developed with data from the first sampling period (May 5) of green herbage to the peak standing crop of blue grama (rising period). Secondly, regression analyses were determined after peak standing crop of herbage to the last sampling period (September 8) with live herbage (declining period). The dependent variable (Y) in all cases was the daily change in herbage weight. Independent variables tested included herbage weight (WT), herbage weight squared $\left(\mathrm{WT}^{2}\right)$, nitrogen content $(\mathrm{N})$, leaf moisture content (LM), air temperature $(\mathrm{T})$, average precipitation per day and soil moisture. The value of these independent variables are used to predict the daily change in herbage weight at 2-week intervals, from date $a$ to date $b$. Only those independent variables which contribute significantly to the dependent variable are presented.

Net rates of changes for blue grama herbage were quite variable during the two year study. During the rising period from the beginning of growth to maximum yields, the mean changes were $0.48 \mathrm{~g} / \mathrm{m}^{2} /$ day over all replicates. Variations were found in the declining period, with a mean value of -0.26 $\mathrm{g} / \mathrm{m}^{2} /$ day. During the two years, live blue grama ranged from $0.43 \mathrm{~g} / \mathrm{m}^{2}$ to a high of $63 \mathrm{~g} / \mathrm{m}^{2}$ among the replicates.

Leaf moisture was quite variable during both years, ranging from $27 \%$ to $91 \%$ during the rising period to peak standing crop and varying from $84 \%$ to $29 \%$ in the declining period.

On the Pawnee Site, $54 \%$ of the variation in changes of live herbage was accounted for by the weight of herbage present (WT) during the rising period (Equation 3, Table 2). The parabolic equation shows that a curvilinear relationship exists between standing crop of blue grama and net rate of changes in herbage (Fig. 1). This equation could be used to predict changes in herbage yields and stocking rates could be adjusted accordingly.

During the declining period, $47 \%$ of the variation in net changes of live herbage was accounted for by the amount of live herbage and its leaf moisture. Equation 6 could be used to predict the herbage changes after peak biomass, which occurs when blue grama is in the bud stage to early anthesis. Stocking rates for livestock could be appropriately adjusted for the

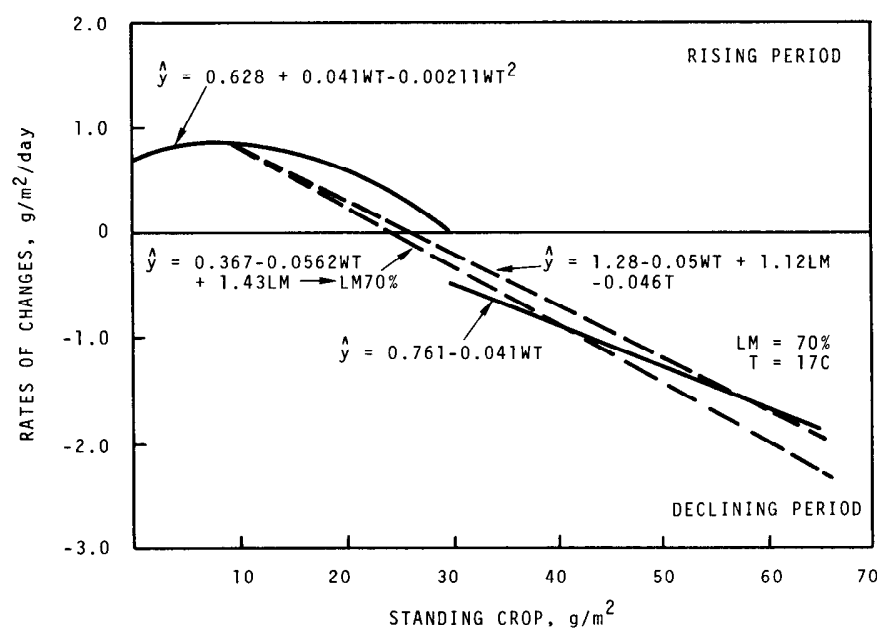

Fig. 1. Predicting net rates of change for live blue grama herbage during the rising and declining periods. remaining growing season.

Equation 10 is a general equation following the time of maximum rate of change (Y) and may be used in place of Equation 6. This equation could be used to predict the rate of change of live blue grama during the declining period of changes for herbage. During this period, $58 \%$ of the variation is accounted for by the amount of live blue grama herbage present, its leaf moisture and the mean ambient air temperature (T). Herbage decreases as a function of WT and T, but increases as a function of leaf moisture.

The declining period for herbage may be a result of transpiration stress. When a certain amount of herbage is present and air temperatures incrcase, the decreases are probably due to this stress, although other biological factors may function during the declining period.

Date means for rates of changes in green blue grama herbage combined over treatments for both years were analyzed by the procedure outlined earlier. Higher $\mathrm{R}^{2}$ values (0.74-0.84) were obtained for the rising period, indicating that the variability between and among replicates was high. During the rising period temperature was the most important independent variable, followed by the amount of herbage present, precipitation, and leaf moisture. The contributions of these independent variables were significant, but the high correlations may be the result of few data points. The declining period showed that leaf moisture and precipitation were the two most important independent variables, although $\mathrm{R}^{2}$ values were lower than those presented for the rising period.

Predicting the amount of herbage would be useful in working out stocking rates for blue grama during the period of rapid vegetative growth and also during the declining period. The equations developed may be used for modeling purposes (e.g., Smith and William, 1973) and the method for predictions may also be used for other types of research studies.

\section{Flow Model of Herbage}

The model shown in Figure 2 outlines the flow of herbage from one compartment to another. Increases of live herbage result from carbon dioxide being fixed through photosynthesis and transferred to the live compartment after April of each

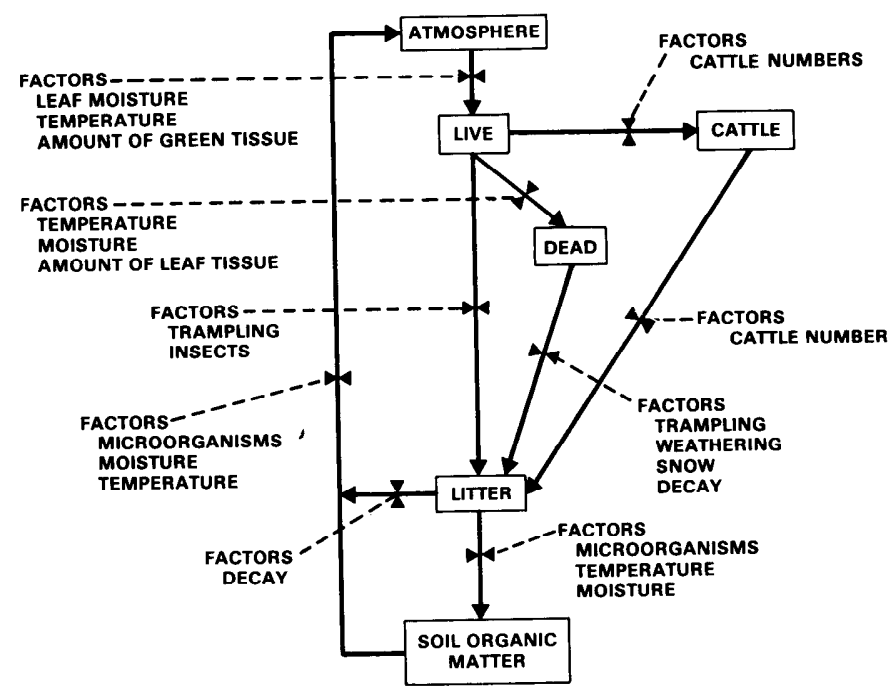

Fig. 2. , Compartmental model of factors affecting rates of flow of blue grama herbage. 
year. These increases usually begin when the mean air temperature is approximately $4^{\circ} \mathrm{C}$. During this early growth period, the changes of herbage are a function of the following equation:

$$
\mathrm{Y}=0.628+0.041 \mathrm{WT}-0.0021 \mathrm{WT}^{2}
$$

where WT is the amount of live herbage present at a given time. The changes may be dependent upon leaf moisture.

After $9.7 \mathrm{~g} / \mathrm{m}^{2}$ of live herbage accumulates, daily rates of change begin to decrease. The rates of change may now be estimated by the equation:

$$
\mathrm{Y}=1.281-0.05 \mathrm{WT}+1.22 \mathrm{LM}-0.046 \mathrm{~T} \text {. }
$$

It appears that flows to standing dead may be related to the amount of live herbage and mean air temperatures, while flows to live herbage may be related to leaf moisture. The transfer of live to dead herbage during the growing season was approximately $0.22 \%$ of the live herbage per day over 150 days (Uresk, 1971). When the air temperatures reach $0^{\circ} \mathrm{C}$ or killing frost, increases in dead herbage are equal to the amount of live herbage present. Factors affecting this rate of transfer are temperature, desiccation of the plant, and the amount of live tissue present.

Cattle consumed live and dead herbage from May 1 to September 30 of each year. The transfer rate to cattle is approximately $4.7 \times 10^{-3} \mathrm{~g} / \mathrm{m}^{2} /$ head/day on 129.5 ha on a dry matter basis (Bement, 1971, personal communication). The amount of excreta entering the litter compartment is approximately $2.4 \times 10^{-3} \mathrm{~g} / \mathrm{m}^{2} /$ head/day.

Litter may increase from live herbage because of rain, hail, wind, insects, trampling by large herbivores and fecal excretion. Litter accumulation from dead herbage during the summer was approximately $0.31 \%$ of dead herbage per day for 150 days. Factors influencing this rate are moisture and temperature, which influence decay rates, and trampling. During the winter the transfer from dead to litter is about $0.086 \%$ of the dead herbage per day for 215 days. This increase in litter may be dependent upon the amount of snow.

Litter transferred to soil organic matter during the early spring and summer was approximately $0.35 \%$ of the litter per day for 150 days. Carbon dioxide would be released into the atmosphere upon decomposition of the soil organic matter. Factors affecting these rates of decay are microorganisms, temperature, and moisture.

\section{Literature Cited}

Albertson, F. W. 1966. Ecological studies of blue grama grass
(Bouteloua gracilis). Ft. Hays Studies. Sci. Series No. 5. 37 p.

Bement, R. E. 1968. Herbage growth rate and forage quality on shortgrass range. PhD Diss., Colo. State Univ., Fort Collins. 53 p.

Cavender, B. R., and R. M. Hansen. 1970. The microscope method for herbivore diet estimates and botanical analysis of litter and mulch at the Pawnee Site. Grasslands Biome. U. S. Int. Biol. Program Tech. Rep. No. 18.9 p.

Costello, D. V., and G. T. Turner. 1941. Vegetation changes followed exclusion of livestock from grazed ranges. J. Forest. 39:310-315.

Currie, P. O., and G. Peterson. 1966. Using growing-season precipitation to predict crested wheatgrass yields. J. Range Manage. 19:284-288.

Dahl, B. E. 1963. Soil moisture as a predictive index to forage yield for the sandhills range type. J. Range Manage. 18:94-96.

Draper, N. R., and H. Smith. 1968. Applied regression analysis. John Wiley and Sons, Inc., New York. 407 p.

Flake, L. D. 1973. Food habits of four species of rodents on short-grass prairie in Colorado. J. of Mammal. 54:636-647.

Flinders, J. T., and R. M. Hansen. 1972. Diets and habits of jackrabbits in northeastern Colorado. Range Sci. Dep., Ser. 12.29 p.

Fracker, S. B., and J. A. Brischle. 1944. Measuring the local distribution of Ribes. Ecology 25:283-303.

Galbraith, A. F. 1971. The soil-water regime of the shortgrass prairie ecosystem. PhD Diss., Colo. State Univ., Fort Collins. 127 p.

Hansen, R. M., and J. T. Flinders. 1969. Food habits of North American hares. Colo. State Univ., Range Sci. Dep., Ser. 1. 17 p.

Howard, W. E. 1962. Rangeland insects and rodent pests. p. 191-193. In Pasture and range research techniques. Comstock Publ. Ass., Ithaca, New York. $242 \mathrm{p}$.

Hulett, G. K., and G. W. Tomanek. 1969. Forage production on a clay upland site in western Kansas. J. Range Manage. 22:270-276.

Klipple, G. E., and D. F. Costello. 1960. Vegetation and cattle responses to different intensities of grazing on shortgrass ranges on the central Great Plains. Forest Serv., Rocky Mountain Forest and Range Exp. Sta., Tech. Bull. 1216. 82 p.

Rauzi, R. 1964. Late-spring herbage production on shortgrass rangeland. J. Range Manage. 17:210-212.

Shiflet, T. N., and H. E. Dietz. 1974. Relationship between precipitation and annual rangeland herbage production in sou theastern Kansas. J. Range Manage. 27:272-276.

Smith, F. M., and W. D. Striffler. 1969. Pawnee Site microwatersheds: selection description and instrumentation. Grasslands Biome. U. S. Int. Biol. Program Tech. Rep. No. 18.9 p.

Smith, R.C.G., and W. A. Williams. 1973. Model development for a deferred-grazing system. J. Range Manage. 26:454-460.

Smoliak, S. 1956. Influence of climatic conditions on forage production of shortgrass rangeland. J. Range Manage. 9:89-91.

Sparks, D. R., and J. C. Malechek. 1968. Estimating percentage dry weight in diets using a microscope technique. J. Range Manage. 21:264-265.

Stoddart, L. A., and A. D. Smith. 1955. Range management. McGraw-Hill Book Co., New York. 433 p.

Uresk, D. W. 1971. Dynamics of blue grama within a shortgrass ecosystem. PhD Diss., Colo. State Univ., Fort Collins. 52 p.

Yount, V. A. 1971. Diets of selected insects in a grassland ecosystem. MS Thesis, Colo. State Univ., Fort Collins. 95 p.

\title{
DIRECTOR
}

\section{Institute of Agriculture and Land Resources Management}

The University of Alaska is seeking a Director of the Institute of Agriculture and Land Resources Management. Applicants should have at least 10 years experience, as well as a $\mathrm{PhD}$, in one of the disciplines.

* Position available on July 1975. Salary commensurate with qualifications and University of Alaska scales.

The University of Alaska is an equal opportunity and affirmative action employer.

Enquiries should be addressed to:

\author{
Institute of Agricultural Sciences \\ Palmer Research Center \\ Palmer, Alaska 99645
}

